\title{
Rhombohedral crevasse-fill ridges at the marine margin of a surging Svalbard ice cap
}

\author{
J. A. DOWDESWELL ${ }^{1}$, A. SOLHEIM ${ }^{2} \&$ D. OTTESEN ${ }^{3}$ \\ ${ }^{1}$ Scott Polar Research Institute, University of Cambridge, Cambridge CB2 1ER, UK \\ ${ }^{2}$ Norwegian Geotechnical Institute, Postboks 3930, Ulleval Stadion, N-0806 Oslo, Norway \\ ${ }^{3}$ Geological Survey of Norway, Postboks 6315 Sluppen, N-7491 Trondheim, Norway \\ *Corresponding author (e-mail: jd16@cam.ac.uk)
}

The ice cap of Ausftonna in eastern Svalbard is the largest in the Eurasian Arctic at $8,000 \mathrm{~km}^{2}$ and has about $200 \mathrm{~km}$ of marine-terminating ice cliffs (Dowdeswell et al. 2008). Several of its drainage basins are of surge-type (Meier \& Post 1969) and between 1936 and 1938 one of these basins, Bråsvellbreen $\left(1,100 \mathrm{~km}^{2}\right)$, increased its velocity rapidly and underwent an advance of about $20 \mathrm{~km}$ along a $30 \mathrm{~km}$-wide front (Schytt 1969). Since that time the ice-cap terminus has stagnated and retreated, losing mass by a combination of surface melting, thinning and iceberg production. Retreat has revealed several distinctive and well-preserved submarine landforms (Fig. 1) linked to this recent surge activity (Solheim \& Pfirman 1985; Solheim 1991).

\section{Description}

Three types of sedimentary landform are observed in seafloor swath-bathymetric and side-scan sonar imagery from offshore of the modern terminus of Bråsvellbreen (Fig. 1a, d). The first is a series of intersecting small ridges which form a rhombohedral or 'box-work' pattern, with individual elements both parallel and transverse to past glacier flow (Solheim \& Pfirman 1985; Solheim 1991). These features occur between the maximum extent of the 1936-38 ice advance (Fig. 1b) and the limit of our data close to the modern ice front. The small ridges are typically about $5 \mathrm{~m}$ high (Fig. 1e), spaced about $50 \mathrm{~m}$ apart and form a rhombohedral pattern (Fig. 1a, d). Along with these features are some discontinuous and arcuate ridges usually sub-parallel to the ice front and found closest to the modern glacier terminus (Solheim \& Pfirman 1985). In addition, there are a few hummocks or irregular mounds of debris, up to about $10 \mathrm{~m}$ high (Fig. 1a). The sediments have been sampled and are mainly pebbly muds, typical of diamictic glacial debris (Solheim 1991).

A second feature is a single prominent ridge that is orientated sub-parallel to the present ice-cap terminus, which is linked to the maximum ice-front position during the 1936-38 rapid surge advance of Bråsvellbreen. The ridge is continuous along the approximately $30 \mathrm{~km}$ of the ice-cap terminus and varies in height from 8 to $20 \mathrm{~m}$ above the general level of the seafloor; its width is between 500 and 1,700 $\mathrm{m}$ (Solheim \& Pfirman 1985). Ice-distal slopes are $2-3^{\circ}$ and are $4-6^{\circ}$ on the ice-proximal flank. A seismic reflection can be traced beneath the ridge (Fig. 1f), marking the contact with older pre-surge sediments.

Finally, both these landforms are cross-cut by a series of curvilinear depressions, sometimes with marginal berms, that are overlaid chaotically on the other two features (Fig. 1a). These curvilinear forms are most common on the major ridge, which is the shallowest part of the image, but also occur both onshore and offshore of this large landform; one is continuous across the whole $2.5 \mathrm{~km}$ of the image.

\section{Interpretation}

The rhombohedral pattern of intersecting small ridges (Fig. 1a, d, e) is interpreted to have been formed by the squeezing up of soft diamictic sediment into basal crevasses and hollows in the base of Bråsvellbreen (Solheim \& Pfirman, 1985). Similar processes have been inferred to operate beneath surge-type glaciers in Iceland, where subaerial crevasse-fill ridges have been observed 
(Sharp 1985). Basal debris is likely to have been under high water-pressure during the active phase of the surge cycle, providing a mechanism for substrate deformation, explaining fast glacier flow and terminus advance. The active phase of a surge is thought to end when ice flow from an upper reservoir area on a glacier begins to slow and pressurised water is released from the bed (Kamb et al. 1985); the ice then stagnates. The delicate ridges were preserved on the seafloor after ice retreat, which was probably by the thinning and calving of stagnant ice during the quiescent period of the surge cycle. This prevented the rhombohedral ridges from being reworked by subsequent glacier motion. The small sub-parallel ridges closest to the modern ice margin may be a result of renewed, although slow forward motion of the ice, producing small push moraines during winter readvances superimposed on continuing overall terminus retreat (Solheim \& Pfirman 1985; Ottesen \& Dowdeswell 2006).

The prominent, continuous large ridge running parallel to the ice-cap margin (Fig. 1a, f) is interpreted as the terminal moraine that marks the maximum extent of the 1936-38 surge of Bråsvellbreen (Fig. 1b). The ridge's total volume, calculated along its c. $30 \mathrm{~km}$ length, is about 0.5 $\mathrm{km}^{3}$ of debris (Solheim \& Pfirman 1985). It was probably formed by mechanical pushing of soft diamictic sediments during the surge-related terminus advance, but may also have a meltwaterdelivered component linked in particular to the drainage of basal water that usually takes place at the end of the active phase of the surge cycle (Kamb et al. 1985; Solheim \& Pfirman 1985). There are some small slumps on the ice-distal side of the ridge, indicating rapid deposition (Solheim 1991), but these are difficult to see on the multibeam imagery.

The curvilinear and irregularly spaced depressions that cross-cut the crevasse-fill ridges and terminal moraine (Fig. 1a) are interpreted as ploughmarks produced by iceberg keels impinging on the sedimentary seafloor (Solheim 1991). Many icebergs were calved during the surge of Bråsvellbreen (Fig. 1b), and over the decades since surge termination the ice front has retreated by about $40 \mathrm{~m} \mathrm{yr}^{-1}$, producing about $0.4 \mathrm{~km}^{3} \mathrm{yr}^{-1}$ of icebergs (Dowdeswell et al. 2008).

\section{References}

DOWDESWELL, J. A., BENHAM, T. J., STROZZI, T. \& HAGEN, J. O. 2008. Iceberg calving flux and mass balance of the Austfonna ice cap on Nordaustlandet, Svalbard. Journal of Geophysical Research, 113, doi:10.1029/2007JF000905

KAMB, B., RAYMOND, C. F., et al. 1985. Glacier surge mechanism: 1982-1983 surge of Variegated Glacier, Alaska. Science, 227, 469-479.

MEIER, M. F. \& POST, A. 1969. What are glacier surges? Canadian Journal of Earth Sciences, 6 , 807-817.

OTTESEN, D. \& DOWDESWELL, J.A. 2006. Assemblages of submarine landforms produced by tidewater glaciers in Svalbard. Journal of Geophysical Research 111, F01016.

SCHYTT, V. 1969. Some comments on glacier surges in eastern Svalbard. Canadian Journal of Earth Sciences, 6, 867-871.

SHARP, M. 1985. Crevasse-fill ridges - A landform type characteristic of surging glaciers. Geografiska Annaler, 67A, 213-220.

SOLHEIM, A. 1991. The depositional environment of surging sub-polar tidewater glaciers: a case study of the morphology, sedimentation and sediment properties in a surge-affected marine basin outside Nordaustlandet, northern Barents Sea. Norsk Polarinstitutt Skrifter, 194, 97 pp.

SOLHEIM, A. \& PFIRMAN, S. L. 1985. Sea-floor morphology outside a grounded, surging glacier; Bråsvellbreen, Svalbard. Marine Geology, 65, 127-143.

Fig. 1. (a) Rhombohedal ridges and a terminal moraine ridge on the seafloor offshore of Bråsvellbreen, an outlet of the Austftonna ice cap in eastern Svalbard. Image courtesy of the Norwegian Hydrographic Service (Permission no. 14/G754). Acquisition system: Kongsberg EM1002. Frequency: $97 \mathrm{kHz}$. Grid-cell size $3 \mathrm{~m}$. The ridges are interpreted to have been formed by the filling of basal crevasses with deforming diamictic sediment. (b) Oblique aerial photograph of 
the surge and rapid advance of Bråsvellbreen in 1938 (Photo S38-1958; courtesy of Norsk Polarinstitutt). (c) Map of Svalbard with the study shown as a red box (from IBCAO v. 3). (d) Sidescan sonar image of the rhombohedral moraine ridges offshore of Bråsvellbreen $\left(79^{\circ} 12^{\prime} \mathrm{N}, 23^{\circ} \mathrm{E}\right.$, about $5 \mathrm{~km}$ southeast of (a)) (modified from Solheim \& Pfirman 1985). Acquisition system: Klein. Frequency: $50 \mathrm{kHz}$. (e) Sub-bottom profile of rhombohedral ridges $\left(79^{\circ} 11^{\prime} \mathrm{N}, 23^{\circ} 24^{\prime} \mathrm{E}\right.$, about 15 $\mathrm{km}$ southeast of (a)) (modified from Solheim \& Pfirman 1985). VE x 10. Acquisition system: ORE sub-bottom profiler. Frequency $3.5 \mathrm{kHz}$. (f) Sparker profile across the terminal moraine marking outer limit of the 1936-38 surge with the ice cap to the right $\left(79^{\circ} 08^{\prime} \mathrm{N}, 23^{\circ} 48^{\prime} \mathrm{E}\right.$, about $25 \mathrm{~km}$ southeast of (a)) (modified from Solheim \& Pfirman 1985). VE x 5. Acquisition system: EG\&G Sparker. Frequency: single-channel streamer, 100-600 Hz filter. 

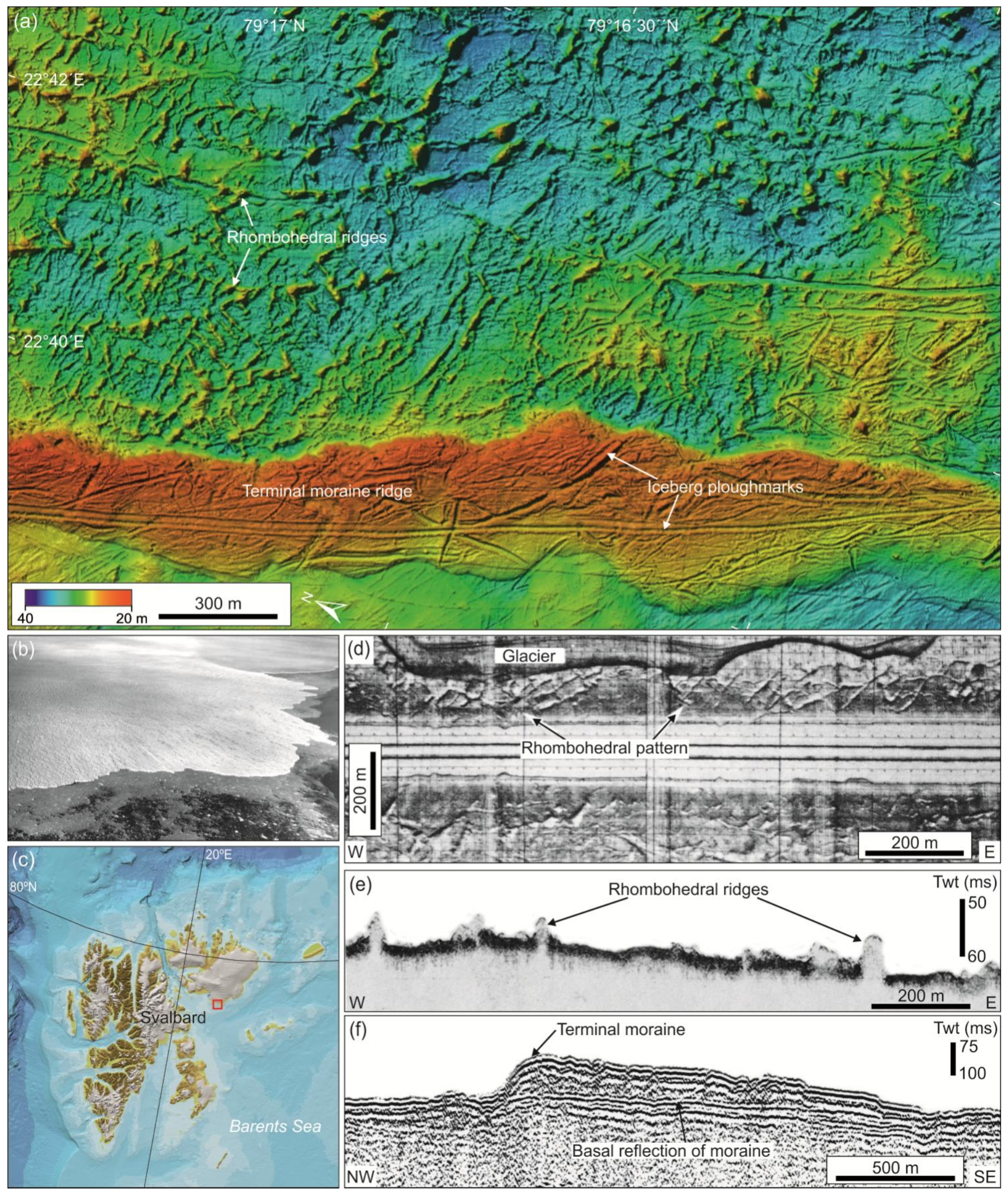